\title{
Wybrane konflikty na scenie politycznej Polski $w$ latach 1989-2014
}

$\mathrm{K}$ LUCZOWYM POJĘCIEM STOSOWANYM W NINIEJSZYM ARTYKULE JEST POJĘCIE konfliktu politycznego, czyli sytuacji rywalizacji między dwoma albo większą ilością podmiotów polityki posiadających wzajemnie sprzeczne interesy i zmierzających do osiągnięcia pozytywnie wartościowanych dóbr materialnych i niematerialnych przez zdobycie, utrzymanie i sprawowanie władzy - przy jednoczesnym ograniczeniu możliwości działania, zneutralizowaniu bądź zniszczeniu przeciwnika (Leksykon, s. 174 - 175). Cezura czasowa, jaką zastosowano w tejże publikacji to lata 1989-2014. Wybranie jej było spowodowane chęcią przedstawienia konfliktów politycznych w pierwszych latach po wykształceniu się w Polsce nowego demokratycznego ładu, jak i konfliktów współczesnych. Podział na dwa okresy - pierwszy, obejmujący konflikty od roku 1989 do dnia wyborów parlamentarnych w roku 2005 i drugi, rozpoczynający się od dnia wyborów parlamentarnych w roku 2005 do roku 2014, pozwolił na wskazanie cech specyficznych dla każdej z obydwu grup oraz dostrzeżenie różnic między nimi. Napisanie niniejszego artykułu służyć miało odpowiedzi na pytanie o ewolucję i istotę współczesnych konfliktów politycznych oraz ukazanie czytelnikom, że są one immanentną cechą życia politycznego Polski.

\section{DEFINICJA, GENEZA ORAZ SPOSOBY ROZSTRZYGANIA KONFLIKTÓW}

SFORMUŁOWANIE 'KONFLIKT POLITYCZNY' POCHODZI OD ŁACIŃSKIEGO SŁOWA conflictus, oznaczającego zderzenie. Jak już wspomniano wcześniej, o konflikcie politycznym mowa jest, gdy dwa albo większa ilość podmiotów politycznych posiada wzajemnie sprzeczne interesy i zmierza do osiągnięcia określonych dóbr. Konflikt polityczny powstaje wówczas, gdy podmioty uświadomią sobie przyczyny ograniczeń w realizacji ich interesów i podejmą działania skierowane na likwidację tych przeszkód. Konflikt polityczny jest czynnikiem dynamizującym, co oznacza, że system polityczny oraz jego otoczenie mogą prowadzić 
do jego modernizacji, regresu, zmiany ewolucyjnej i zmiany rewolucyjnej (Leksykon, s. 174 - 175). Jak pisze Leszek Sobkowiak, warunkiem, który musi spełnić konflikt, by być konfliktem politycznym, musi być jego pośredni i/lub bezpośredni związek z systemem politycznym. Według L. Sobkowiaka istotę konfliktu politycznego stanowi władza polityczna, rozumiana jako sfera, a zarazem zdolność regulowania potrzeb, interesów, świadomości oraz interakcji społecznych w makroskali, mezoskali i mikroskali (Sobkowiak, 1999, s. 126). Janusz Sztumski zauważa, że walka między partiami politycznymi może być też definiowana jako jeden z rodzajów konfliktu społecznego (Sztumski, 1987, s. 106).

Wspominając o genezie sytuacji konfliktowych, wspomnieć należy o różnorodności przyczyn konfliktów i teorii na ich temat. W najprostszym ujęciu, ludzie walczą ze sobą, gdy chcą wejść w posiadanie tego samego dobra albo gdy mają różne pomysły na realizację jakiegoś celu. Podobne przyczyny konfliktów występują także w przypadku grup społecznych.

Jedną z wyodrębnionych przez J. Reykowskiego sytuacji prowadzących do konfliktów jest różnica interesów. Konflikt tego typu, w którym główną rolę odgrywa różnica w interesach, nasila się w sytuacjach, w których pogarsza się dostęp do zasobów ważnych dla egzystencji danej grupy. Aby to zrozumieć, należy dokładniej poznać sytuację grup i ich interesy. Wówczas możliwe jest pojęcie, kiedy dana grupa będzie czuła zagrożenie ze strony innej grupy oraz zrozumieć źródła ich wzajemnej wrogości. Ludzie w sytuacjach konfliktowych wywoływanych różnicami interesów kierują się różnymi strategiami. Wyróżnić można w tym miejscu, strategię rywalizacyjną, polegającą na maksymalizowaniu własnej korzyści kosztem partnera oraz strategię kooperacyjną, która z kolei polega na współdziałaniu w celu realizacji interesów obu stron.

Kolejną przyczyną prowadzącą do pojawienia się konfliktu politycznego są różnice społecznej tożsamości (Reykowski, 2002, s. 211219). Teoria społecznej tożsamości, nazywana także teorią społecznej kategoryzacji, za punkt wyjścia obrała analizę pewnych właściwości poznawczego funkcjonowania człowieka. Jednym z podstawowych warunków orientacji w otaczającym nas świecie jest ujmowanie zjawisk w pewne grupy czy klasy i nadawanie im nazw, czyli kategoryzacja. Wszystko, co człowiek poznaje, zostaje przypisane do jakiejś kategorii, co prowadzi do formułowania pewnej oceny. Dzięki temu porządkujemy bodźce, które do nas docierają. W związku z tym, 
od nazwania pozytywnego lub negatywnego określenia człowieka zależy, jakie wywołuje to w naszym umyśle oczekiwania i wyobrażenia. Kategoryzacja prowadzi do postrzegania ludzi w dwóch grupach, a mianowicie ,swoich” oraz ,obcych”. Swoi to ci należący do grupy, do której sami należymy, obcy to natomiast osoby z innych grup. Prowadzi to do sytuacji niedostrzegania różnic między członkami własnej grupy i przeceniania różnic między członkami innych grup oraz do tego, że członkom swojej grupy przypisujemy pozytywne cechy, natomiast ludziom $\mathrm{z}$ innych grup cechy negatywne (Reykowski, 2002, S. 211 - 219).

Według Ralfa Dahrendorfa istnieją trzy sposoby rozstrzygania konfliktów (Leksykon, s. 175 - 176). Pierwszym z nich jest rozwiązywanie konfliktu, które polega na próbie jego zniesienia przez wyeliminowanie jego przyczyn. Drugim jest tłumienie konfliktu, czyli zablokowanie przeciwstawnych działań stron. Regulacja konfliktu opiera się z kolei na założeniu o niemożności ostatecznego rozwiązania pewnych konfliktów, będących stałymi elementami życia społecznego, w związku z czym pozostają jedynie próby kontroli przejawów konfliktu bez naruszania jego przyczyn. Regulacja przyjmuje formę pojednania, pośrednictwa i arbitrażu (Leksykon, s. 175 - 176).

Inna koncepcja rozstrzygania konfliktów składa się z czterech metod. Pierwszą jest strategia dominacji, oznaczająca próbę osiągnięcia celów własnych bez uwzględnienia dążeń strony przeciwnej, w której można stosować groźby, perswazję i przemoc. Strategia wycofania oznacza z kolei rezygnację z osiągnięcia celów, co wiąże się z akceptacją zwycięstwa przeciwnika. Strategia bierności to niepodejmowanie działań w nadziei, że konflikt samoistnie wygaśnie. Strategia rozwiązywania zmierza do określania metod i proporcji ,jednoczesnej realizacji niektórych przynajmniej interesów obu stron" (Leksykon, s. 175 - 176).

Janusz Mucha zauważa, że konflikty mogą dotyczyć bardzo różnych problemów i mieć różne podłoże, różne fazy i przebieg, jednak stwierdzić można, że są istotnymi elementami rzeczywistości. Przy tym założeniu należy przyjąć, że przynajmniej niektórych z nich po prostu nie da się wyeliminować, można je co najwyżej tłumić (Mucha, 1978, s. 168 - 169). Ku tezie, że konflikt między ugrupowaniami politycznymi, reprezentującymi różne środowiska społeczne i ich nierzadko sprzeczne interesy jest istotnym elementem życia codziennego w demokratycznym państwie skłania się także Agnieszka Golec (Golec, 2002, s. 11). Podkreśla też, że w ocenie wielu osób konflikt polityczny 
jest jednak czymś negatywnym i niepożądanym. Teoretycy przypisują jednak konfliktom politycznym wartości konstruktywne, argumentując to tym, że pozwalają one na wyrażenie opinii różnym grupom społecznym. Najbardziej spektakularnym rodzajem konfliktu politycznego jest ten o przebiegu destrukcyjnym, w którym strony nie wyrażają chęci porozumienia i nie zważają na dążenia przeciwnika. Zdarzają się jednak konflikty polityczne o pozytywnych konsekwencjach, pozwalające na poszukiwanie nowych, twórczych rozwiązań zapewniających realizację interesów wszystkich zaangażowanych stron (Golec, 2002, s. 11).

Wydaje się, iż w polityce najczęstszą przyczyną konfliktów jest sprzeczność interesów, zdarza się jednak, że pomimo dążenia do tych samych celów, strony angażują się w spory. Nawet pozorna chęć współpracy może doprowadzić do nieporozumienia. W kolejnych latach po wykształceniu się w Polsce ładu demokratycznego dochodziło do nowych potyczek, co jest przedmiotem rozważań w dalszej części niniejszego szkicu. Warto podkreślić, iż system demokratyczny, z uwagi na występowanie pluralizmu politycznego, stanowi podatny grunt do kształtowania się takich sytuacji.

KSZTAŁTOWANIE SIĘ DEMOKRATYCZNEGO ŁADU ORAZ WYBRANE KONFLIKTY W LATACH 1989-2005

Korzenie nowej Polski sięGają cZasów RozPadu Polskiej Rzeczypospolitej Ludowej, która stopniowo zwiększała niezależność i samodzielność narodu polskiego, działalności opozycji demokratycznej, a także działalności Kościoła. Wpływ na zmianę systemową miało też pogarszanie się nastrojów społecznych od połowy lat 80 . XX w. oraz proces deregulacji i przekazywania państwowego mienia podmiotom prywatnym.

Reformy polityczne były jednym z głównym tematów obrad Okrągłego Stołu, które rozpoczęły się 6 lutego 1989 r. Już wtedy dochodziło na tym tle do sporów, szczególnie w kwestii ordynacji wyborczej, kompetencji prezydenta i relacji między Sejmem i Senatem. Niezależny Samorządny Związek Zawodowy „Solidarność” zgodził się na niedemokratyczny charakter wyborów z zastrzeżeniem, żeby ordynacja dotyczyła tylko jednej kadencji parlamentu. Władze komunistyczne z kolei chciały nie tylko odpowiedniego podziału mandatów, ale też odpowiedniej reprezentacji opozycji. Podczas posiedzeń Okrągłego Stołu wypracowano zgodę co do sposobu legalizacji Solidarności. Po zakończeniu obrad, 7 kwietnia 1989 r. przyjęto nowelizację Konstytucji Polskiej Rzeczypospolitej Ludowej oraz ustawę Prawo o stowa- 
rzyszeniach. Pierwsze wybory do parlamentu przeprowadzone na zasadach uzgodnionych podczas posiedzeń Okrągłego Stołu wyznaczono na 4 czerwca 1989 r. 425 posłów miało być wybranych w 108 okręgach, a 35 miejsc przeznaczone zostało dla kandydatów z tzw. listy krajowej, przyznanej w całości koalicji rządzącej. Do uzyskania mandatu w okręgu w pierwszej turze niezbędne było otrzymanie ponad połowy ważnie oddanych głosów. W drugiej turze posłem zostawał kandydat, który dostał większą liczbę ważnych głosów. W przypadku listy krajowej posłami zostawali wyłącznie kandydaci, którzy otrzymali ponad połowę głosów (Dudek, 2007, s. 11 - 28).

System partyjny w roku 1989 nie miał jednak oparcia w społeczeństwie, a partie nie tworzyły żadnej więzi z grupami społecznymi, nie zdążyły się bowiem zakorzenić w strukturze społecznej. Powstające $\mathrm{w}$ tamtych czasach ugrupowania nie były raczej odzwierciedleniem interesów określonych grup społecznych (Sielski, 2007, s. 43 - 44).

$\mathrm{Na}$ czele pierwszego niekomunistycznego rządu w Polsce stanął Tadeusz Mazowiecki, urodzony w 1927 r. w Płocku. Aktywność polityczną zaczął od wstąpienia do Stronnictwa Pracy w 1946 r., którego jednak działanie zostało zawieszone. Współpracował z tygodnikiem „Dziś i Jutro” oraz był działaczem Stowarzyszenia PAX i redaktorem naczelnym „Wrocławskiego Tygodnika Katolickiego”. Współtworzył Solidarność, uczestniczył też w negocjacjach poprzedzających obrady Okrągłego Stołu (Życiorys, dostęp: o8.03.2014r.). Wystąpieniem w Sejmie z 24 sierpnia 1989 r. zapowiedział, że celem jego rządu jest przezwyciężenie kryzysu ekonomicznego poprzez ,,powrót do gospodarki rynkowej oraz roli państwa zbliżonej do rozwiniętych gospodarczo krajów" (Dudek, 2007, s. 55). Po tym przemówieniu oficjalnie powierzono mu funkcję premiera. Zasadą polityki T. Mazowieckiego okazało się unikanie sporu z Polską Zjednoczoną Partią Robotniczą i jej spadkobiercami. Choć początkowo strategia ta wydawała się zrozumiała, stała się przedmiotem ostrej krytyki. Była także jedną z przyczyn rozpadu obozu solidarnościowego. Przyczyną pierwszego poważnego konfliktu politycznego czasów rządu T. Mazowieckiego był fakt, że już przy konstruowaniu gabinetu, kierownictwo PZPR domagało się od niego dla swoich członków miejsc w Ministerstwie Spraw Zagranicznych, Ministerstwie Finansów, Transportu i Łączności oraz kontroli nad Komitetem ds. Radia i Telewizji. Ostatecznie konflikt ten udało się zażegnać przy pomocy kompromisu: sekretarzem stanu w resorcie MSZ został członek PZPR, która w zamian za rezygnację ze stanowiska ministra finansów otrzymała resort współpracy gospo- 
darczej z zagranicą oraz obietnicę poparcia przez Sejm kandydatury Władysława Baki na prezesa Narodowego Banku Polskiego.

Bezpośrednią przyczyną kolejnej potyczki stało się odsunięcie od rozmów na temat rządu Lecha Wałęsy, który winą za taki rozwój wydarzeń obarczył T. Mazowieckiego, kierując pod jego adresem pełne wyrzutu sformułowanie: „To ja pana zrobiłem tym premierem”. Konflikt między nimi zaczął narastać, jednak publicznym faktem stał się dopiero po kilku miesiącach (Dudek, 2007, s. 54 - 58). L. Wałęsa, który pozostawał w Gdańsku, czuł się pozbawiony wpływu na decyzje ówczesnego premiera. Odczuwał też niechęć do T. Mazowieckiego z powodu jego ogromnej popularności, przejawiającej się wówczas poparciem na poziomie ok. 80\% społeczeństwa. Konflikt ten ostatecznie doprowadził do powstania w Komitecie Obywatelskim dwóch opcji politycznych, jednej zdystansowanej wobec rządu i drugiej o przeciwnych poglądach. Przyszła rola L. Wałęsy także była powodem sporów. Jedni go popierali, a drudzy byli mu zdecydowanie przeciwni (Rząd, dostęp: 08.03.2013r.).

Konflikty pojawiały się także między samym premierem a działaczami jego rządu. Mechanizm kontroli płac oraz wysokość kursu złotego, a także zbyt szybkie tempo przygotowania pakietu ustaw gospodarczych doprowadziło do konfliktu między T. Mazowieckim a Leszkiem Balcerowiczem. Premier nie był zadowolony ze zbyt dużej samodzielności tego ostatniego i jego wyraźnego dążenia do narzucenia swej woli innym. L. Balcerowicz z kolei nie był przychylny długim debatom i nieefektywności pracy premiera. Do kolejnego sporu między nimi doszło w związku ze sprawą listu intencyjnego do Międzynarodowego Funduszu Walutowego. Chociaż ten konflikt także udało się rozwiązać, zaowocował on długotrwałą wzajemną niechęcią obu jego uczestników (Dudek, 2007, s. 69-70).

24 listopada $1990 \mathrm{r}$. wybory prezydenckie wygrał skonfliktowany z T. Mazowieckim L. Wałęsa. Nie trzeba była długo czekać na reakcję premiera, który już następnego dnia zdecydował się podać swój gabinet do dymisji. Nowym premierem, 12 stycznia 1991 r. został Jan Krzysztof Bielecki (Rząd, dostęp: o8.03.2013r.).

Kolejnym okresem obfitującym w konflikty polityczne był okres 1991-1992, czyli lata istnienia gabinetu Jana Olszewskiego. Charakterystycznymi sporami były wówczas te między gabinetem a prezydentem L. Wałęsą, spowodowane głównie kwestią obrony narodowej, spraw wewnętrznych oraz polityki zagranicznej. Powodem pierwszego z nich była chęć dokonania przez ministra Jana Parysa rewolucji 
programowej i kadrowej w Ministerstwie Obrony Narodowej i przeniesienie w stan spoczynku wiceadmirała Piotra Kołodziejczyka. Decyzja została podjęta bez wiedzy L. Wałęsy, który był temu przeciwny. Kontrowersję wzbudziła także następna decyzja premiera, a mianowicie nominacja 29-letniego wówczas Radosława Sikorskiego na wiceministra obrony narodowej. Według prezydenta był za młody na tak poważne stanowisko. L. Wałęsa nie krył swojego niezadowolenia z kolejnej podjętej bez konsultacji z nim decyzji,

W tym samym czasie toczył się spór między Janem Parysem a szefem belwederskiego Biura Bezpieczeństwa Narodowego Jerzym Milewskim. Do konfliktu doprowadziła chęć usunięcia J. Parysa z Zespołu MON oraz opór z jego strony wobec projektu nowej doktryny obronnej Polski. Po tych zdarzeniach prezydent skierował do premiera list, w którym zażądał usunięcia J. Parysa ze stanowiska. J. Olszewski nie wyrażał aprobaty wobec tego pomysłu. Kolejne nieporozumienia związane z postacią J. Parysa zmusiły jednak premiera do podjęcia działań. J. Olszewski powołał komisję mającą zbadać zasadność oskarżeń postawionych przez J. Parysa, wyniki jej prac nie zadowoliły jednak prezydenta, a wręcz doprowadzily do kolejnego konfliktu. Już wtedy można było się spodziewać, że prezydent ma w zamiarze zdymisjonowanie premiera. J. Parys nie zrezygnował z dalszych niekonwencjonalnych zachowań. W końcu, po oświadczeniu, w którym uznano jego działania za szkodliwe dla interesów państwa, podał się do dymisji (Dudek, 2007, s. 195 - 198). Po wielu sporach na linii prezydent - premier, 4 czerwca 1992 r. Sejm odwołał rząd J. Olszewskiego. Stało się to po złożeniu przez Jana Rokitę wniosku o wotum nieufności. Wniosek złożony był w imieniu dwóch ówczesnych partii, a mianowicie Unii Demokratycznej i Kongresu Liberalno - Demokratycznego oraz koła poselskiego Polski Program Gospodarczy (20. rocznica, dostęp: 08.03.2014).

W miarę upływu lat i formowania się nowych rządów, dochodziło do nowych konfliktów politycznych. Nie brakowało ich również wtedy, kiedy władzę w Polsce sprawował Sojusz Lewicy Demokratycznej i Polskie Stronnictwo Ludowe.

Pierwszy konflikt wewnątrzkoalicyjny związany był z protestem Waldemara Pawlaka przeciwko objęciu kierownictwa komisji spraw zagranicznych przez Bronisława Geremka, co stanowiło newralgiczny punkt dla zbliżenia SLD z UD. PSL zagroziło wówczas, że nie zgodzi się na to, by Marek Borowski objął funkcję wicepremiera. Konflikt zakończył się ostatecznym zwycięstwem SLD i B. Geremek objął oczekiwane 
stanowisko. Wkrótce jednak doszło do kolejnych sporów, dotyczących tworzenia rządu. W. Pawlak chciał doprowadzić do usunięcia ze składu gabinetu Wiesława Kaczmarka, jednakże ostatecznie zaakceptował sytuację. Sposób sprywatyzowania Banku Śląskiego (dalej: BŚ) stał się kolejną przyczyną konfliktu, tym razem między W. Pawlakiem a M. Borowskim. Ten ostatni protestował przeciwko zwolnieniu przez W. Pawlaka wiceministra finansów, Stefana Kawalca, odpowiedzialnego za prywatyzację BŚ. Podobno była to jednak tylko przykrywka dla faktycznej przyczyny sporu, jaką miała być kwestia dofinansowania Banku Gospodarki Żywnościowej (dalej: BGŻ). W. Pawlak chciał, by BGŻ był głównym bastionem wpływów PSL w świecie finansowym, czemu przeciwny był M. Borowski, który domagał się ograniczenia pomocy finansowej dla banku. Po odejściu M. Borowskiego premier powołał na stanowisko prezesa BGŻ Kazimierza Olesiaka, za którego kadencji BGŻ otrzymał ogromne kwoty z budżetu na realizację zadań, co przejściowo uczyniło go największym bankiem w Polsce. Przeciwko działaniom premiera zdecydowanie opowiadał się SLD, co nie zmienia faktu, że zwycięzcą tego sporu był bez wątpienia W. Pawlak. Nie trzeba było czekać długo na liczne konflikty koalicji z prezydentem L. Wałęsą. Prezydent nie zamierzał rezygnować ze swojego szerokiego zakresu władzy. Otwarty konflikt rozpoczął się w lutym 1994 r. po tym, jak Sejm w pierwszym czytaniu odrzucił zgłoszone przez Belweder dwa projekty ustaw, jeden dotyczący możliwości składania w Sejmie przez grupę 100 tysięcy obywateli własnych projektów konstytucji, drugi z kolei przewidujący samorozwiązanie parlamentu w przypadku odrzucenia przez naród w referendum ustawy zasadniczej uchwalonej przez Zgromadzenie Narodowe. L. Wałęsa postanowił odwołać wówczas swego przedstawiciela Lecha Falandysza z Komisji Konstytucyjnej (Dudek, 2007, s. 275 - 285).

Kolejny konfliktogenny okres polskiej sceny politycznej przypadł na rządy koalicji Akcji Wyborczej Solidarność i Unii Wolności. Konflikty między tymi ugrupowaniami widoczne były jeszcze na poziomie prowadzenia kampanii, jednak były one zgodne co do niezadowolenia z poprzednich rządów, wobec czego po ponad miesięcznych negocjacjach zawiązano koalicję. Spory już od początku wywoływały kwestie liczby wicepremierów, podziału resortów oraz kandydatów do ich objęcia i sposobu obsady stanowisk wojewodów i wicewojewodów. W Sejmie dochodziło do odmiennego głosowania posłów AWS i UW, co przejawiało się np. tym, że UW krytykowało posunięcia kadrowe AWS, natomiast AWS blokowała kandydatów UW na wysokie stano- 
wiska państwowe. Do sporu między tymi partiami doszło także w maju 1998 r., kiedy okazało się, że Polska nie otrzyma funduszy z PHARE (Poland and Hungary: Assistance for Restructuring their Economies), czyli programu udzielania pomocy państwom kandydującym do Wspólnot Europejskich. Choć konflikt ten miał charakter personalny, ponieważ toczył się głównie między Ryszardem Czarneckim a jego zastępcą, Piotrem Nowiną-Konopką, to nie ulega wątpliwości, że stała za nim kwestia rywalizacji stron o kontrolę nad funduszami z Unii Europejskiej. UW zarzucało niekompetencję AWS, która nie pozostając dłużna, zarzuciła UW, że dysponuje w rządzie wpływami nieproporcjonalnie dużymi w stosunku do liczby mandatów w Sejmie. Po tym zdarzeniu wicepremier L. Balcerowicz przeforsował swój projekt wprowadzenia zmian podatkowych, gdzie domagał się podatku liniowego dla osób fizycznych. Wywołało to ogromne oburzenie przywódców AWS, ponieważ według nich informacje te zostały podane do wiadomości publicznej bez żadnych konsultacji. L. Balcerowicz na swoją obronę twierdził, że rozmawiał o swoich pomysłach zarówno z Jerzym Buzkiem, jak i Marianem Krzaklewskim. Do kolejnego konfliktu na linii AWS - UW doszło w listopadzie 1998 r., kiedy Sejm uchwalił głosami AWS wprowadzenie ulg prorodzinnych i przepisów podatkowych niekorzystnych dla związków zawodowych. L. Balcerowicz w związku z tą sytuacją wyraził swój sprzeciw. Kilka miesięcy później koalicja z trudem przetrwała głosowanie nad zgłoszonym przez PSL wotum nieufności dla L. Balcerowicza, którego szczególnym przeciwnikiem był wówczas szef Rządowego Centrum Studiów Strategicznych Jerzy Kropiwnicki. Władze UW domagały się jego dymisji, ale sytuację udało się ostatecznie rozwiązać. (Dudek, 2007, s. 352 - 381).

Jak wskazuje ankieta przeprowadzona przez CBOS w 2000 r., największa grupa osób uważała, że obydwa ugrupowania koalicyjne przyczyniały się w równym stopniu do powstawania konfliktów. Deklarowało tak $38 \%$ badanych. 30\% winą za konflikty obarczało AWS, zdecydowanie mniej, bo $9 \%$ twierdziło, że winne jest UW. Na uwagę zasługuje fakt, iż zwolennicy UW winą za konflikty wewnątrzkoalicyjne obarczali w większości AWS, z kolei wśród zwolenników AWS zdecydowana większość obarczała winą partie w równym stopniu (Opinie, CBOS, 2000).

W roku 2001, kiedy SLD zwyciężył w wyborach, a do samodzielnego rządzenia zabrakło mu zaledwie kilka głosów, postanowiono o ponownym wejściu w sojusz z PSL. Zakładano, że tym razem będzie Stronnictwo wykaże większą dawkę pokory niż w przypadku koalicji 
z 1993 r., stało się jednak inaczej. Okres ten zaowocował ponownymi konfliktami politycznymi. Do pierwszej potyczki doszło już w listopadzie 2011 r., a powodem była kwestia nowelizacji ustawy podatkowej. PSL, reprezentowane wówczas przez Dariusza Grabowskiego skrytykowało decyzje SLD, za co sam D. Grabowski został pozbawiony członkostwa w klubie.

Wrzesień roku 2002 okazała się być czasem kolejnego konfliktu. Spór dotyczył tym razem handlu artykułami rolnymi z Węgrami, a bezpośrednią przyczyną było to, iż Polska w październiku miała znieść cła m.in. na węgierski drób i wieprzowinę, Węgry zaś na polskie słodycze. Według Jarosława Kalinowskiego były to pomysły bardzo niekorzystne. W opozycji do niego stał Jacek Piechota, minister gospodarki. Premier L. Miller rozwiązał konflikt obustronnie, upomnienie dostali obaj politycy. Całe zdarzenie odczytywane było jako element przedwyborczej gry.

W grudniu 2002 r. dochodziło już do konfliktów w samym PSL-u. Powodem był niższy od oczekiwanego wynik partii w wyborach samorządowych oraz kwestia wstąpienia Polski do Unii Europejskiej, czemu część posłów była przeciwna. Styczeń 2003 r. zaowocował konfliktem dotyczącym zawetowania przez prezydenta ustawy PSL o biopaliwach. Ludowcy zamierzali namawiać posłów, by odrzucili prezydenckie weto.

Ostatnim, i jak się okazało najbardziej istotnym w skutkach konfliktem, była sytuacja odrzucenia przez sejm ustawy winietowej. Zanim do tego doszło, politycy SLD i PSL spierali się o tę kwestię przez sześć godzin. SLD zarzucało PSL szantaż. W konsekwencji PSL zagłosowało przeciw własnemu rządowi. SLD uznało, że może rządzić bez PSL-u, a 1 marca 2003 r. premier odbył ostatnią rozmowę z liderem PSL, po czym nastąpił koniec koalicji (PSL-SLD dostęp: 11.03.2014).

Jak widać, konflikty polityczne w latach 1989-2005 to najczęściej konflikty między partiami tworzącymi koalicje. Zdecydowana większość z nich to spory na tle personalnym między poszczególnymi politykami oraz na tle odmiennych zdań co do prowadzonej polityki. Zauważyć można, że bardzo częstymi konfliktami politycznymi są te między rządem a głową państwa, spowodowane przekonaniem prezydenta L. Wałęsy o braku informowania. Ponadto istotne jest to, że konflikty tamtych lat nie były bardzo długie i przeważnie udawało zakończyć się je kompromisami lub ustępstwem którejś ze stron. 
KONFLIKTY POLITYCZNE W LATACH 2005-2014 NA PRZYKŁADZIE KONFLIKTU PO - PIS

NAJISTOTNIEJSZYM Z KONFLIKTÓW POLITYCZNYCH LAT 2005-2014, I TRWAJĄCYM zresztą do dziś, jest konflikt między Platformą Obywatelską a Prawem i Sprawiedliwością. Według badań z 2013 r. przeprowadzonych przez CBOS, 16,1\% z 20\% osób, które uważały, że najpowszechniejszymi konfliktami o podłożu politycznym w Polsce są konflikty między rządem a opozycją wskazuje na konflikt między PO a PiS. 3,3\% tej samej grupy uważało natomiast, że w konflikcie uczestniczą personalnie przede wszystkim Jarosław Kaczyński i Donald Tusk. 33\% ogółu ankietowanych twierdziło, że konflikty polityczne to głównie konflikty między partiami, a spośród nich o,4\% opowiadało się za tym, że spory z innymi generuje D Tusk, o,3\% z kolei, że generuje je J. Kaczyński (Polskie, CBOS, 2013).

W tym miejscu warto wspomnieć o epizodzie IV Rzeczypospolitej, ponieważ z pewnością jest to wydarzenie, które stało się elementem genezy toczącego się od lat konfliktu między obiema partiami i ich przywódcami. Zdefiniować go można jako program wyborczy PiS, mający na celu przebudowę państwa, głęboką zmianę polskiej polityki społecznej i przywrócenie jej moralnego wymiaru, czyli oparcie jej na wartościach i zasadach etycznych. IV RP miała być państwem nowej umowy społecznej, przebudową polskiego życia, czego wyrazem był projekt Konstytucji akcentujący przejście z III do IV RP (Ziętara, 2007, s. 230). Autorka dzieła pt. ,JJęzyki IV RP: podziały społeczno-polityczne w dyskursie polityki” definiuje IV RP w kilku wymiarach. W wymiarze historycznym jest to, według niej, budowa państwa zdekomunizowanego, w wymiarze ekonomicznym jest to państwo solidarne, przeciwstawiające się liberalizacji gospodarczej, w sferze kulturowej z kolei to państwo aksjologicznie tradycyjne, kierujące się chrześcijańskim systemem wartości, opozycyjne wobec postmaterializmu. Z kolei w wymiarze politycznym IV RP to silne państwo o znacznym stopniu scentralizowania władzy (Figiel, 2009, s. 167).

We wrześniu 2005 r., na miesiąc przed wyborami prezydenckimi ,PiS odniosło zwycięstwo w wyborach do Sejmu. Jednak J. Kaczyński nie celebrował zwycięstwa zbyt długo, bo zaczęto przekonywać go, że nie może objąć stanowiska premiera, ponieważ wpłynie to na niepowodzenie jego brata w wyborach prezydenckich. $Z$ sondaży wynikało, że Polacy nie są przychylni wobec sytuacji, w której bracia objęliby dwa najważniejsze stanowiska w państwie (Majewski, Reszka, 2010, rozdział I). Lech Kaczyński przekonywał brata, że mimo wszystko ten powinien objąc stanowisko premiera. Zaczęto rozważać jednak 
kandydaturę Kazimierza Marcinkiewicza, który miał dobre relacje z politykami PO, szczególnie Janem Rokitą, co było niezmiernie ważne, ponieważ koalicja dwóch głównych partii była ważnym elementem kampanii L. Kaczyńskiego. Chciano tym pokazać, że PiS jest skłonne do kompromisów. Tak też się stało. Miesiąc później, 23 października L. Kaczyński wygrał z D. Tuskiem w wyborach prezydenckich. Lider PO poniósł drugą z rzędu porażkę. Wygrany L. Kaczyński zachowywał się skromnie, choć był to wieczór jego tryumfu. Kilka godzin później Michał Kamiński wypowiada słowa do gości wieczoru wyborczego PiSu: „Gdyby nie cisza wyborcza, to bym państwu powiedział, żebyście poszli do bufetu i zjedli ostatnie kanapki w III RP. Za pół godziny na tej sali wystąpi prezydent IV RP!” (Majewski, Reszka, 2010, rozdział I).

Zachowanie przegranego D. Tuska po porażce wspominał Janusz Palikot. Twierdził, że nigdy nie widział lidera PO tak wściekłego, jak wtedy. Mówił, że Tusk: „W oczach miał pretensję i wielką wściekłość. Choć milczał, to cała jego postać wyrażała wszystko" (Wojciechowska, Palikot, 2011, s. 18 - 19).

W tamtym okresie przeprowadzono wybory prezydenckie i parlamentarne w jednym czasie. Partie zabiegały o mandaty w parlamencie oraz urząd prezydenta, w związku z czym była to ,gra o całą pulę”. Obywatele, tak jak i zainteresowane partie byli przekonani, że PO i PiS będą rządzić wspólnie. Same one zapowiedziały, że sformują wspólny rząd. Z sondaży wynikało, że będą one dysponować parlamentarną większością. $Z$ czasem przyszli partnerzy zaczęli walczyć ze sobą o to, która partia zdobędzie więcej głosów. Kampanie zaczęły przybierać charakter rywalizacyjny (Dziemidok-Olszewska, 2007, s. 206 - 207).

Zauważa się, że Polską miała w założeniu rządzić koalicja PO-PiS, w której kolejność skrótów w nazwie sugerowała, iż to PO zdobędzie większość głosów. Zwycięstwo PiS przekreśliło tę możliwość, a także, jak się później okazało, możliwość powstania zapowiadanej koalicji. Spowodowały to też między innymi pierwsze negocjacje dotyczące koalicji, które transmitowane były w telewizji, gdzie politycy zaczęli się natychmiast wzajemnie oskarżać (Dudek, 2007, s. 505).

Jeszcze przed wyborami w 2005 r. D. Tusk stwierdził: „Od początku zakładałem, i dzisiaj ta opinia znajduje bardzo mocne potwierdzenie, że Polsce potrzebny jest duet Platforma-PiS" (Borejza, 2009, s. 11). Liderzy zapewniali wówczas o swojej ideowej bliskości i o planach koalicyjnych. W wyborach wiele osób głosowało przede wszystkim 
na POPiS, a nie PO lub PiS. Właśnie w toku kampanii w 2005 r. doszło do ostrego konfliktu między nimi. Nagle okazało się, że z pozoru współpracujące i bliskie sobie partie odkryły swoją ideową wrogość (Borejza, 2009, s. 11 - 12).

Z pewnością wydarzeniem, które kilka lat później podgrzało na nowo spór między PO a PiS była katastrofa smoleńska w 2010 r. Politycy PiS oskarżyli najważniejsze osoby w państwie o zdradę i udział w zamachu. Grzegorz Schetyna stwierdzil, że sytuacja, która miała miejsce podczas drugiej rocznicy feralnego zdarzenia doprowadziła do zaostrzenia konfliktu, pojawienia się w polityce wojennego i agresywnegojęzyka, a za swoje słowa politycy PiS powinni wówczas odpowiedzieć przed prokuraturą, ponieważ było to w jego ocenie łamanie prawa (Piechociński, Konflikt PO). J. Palikot, który w tamtym okresie był politykiem PO, także nie szczędził gorzkich słów pod adresem PiS. Uznał, żeówczesny prezydentbyłmoralnieodpowiedzialnyza katastrofę i zalecił sprawdzenie, czy nie był on pod wpływem alkoholu wsiadając do samolotu (Polskie Radio wraca). W dwa lata po katastrofie stanowisko w tej sprawie zajął także Janusz Piechociński. Stwierdził, że konflikt między partiami eksplodował do rozmiarów wcześniej niespotykanych, a politycy PO i PiS to zapiekli wrogowie. Ocenił, że wypowiedzi, które wówczas padały, były niczym w porównaniu z tym, co miało miejsce w Sejmie. Dodał także, że słowa używane w debacie publicznej i kwestionowanie suwerenności własnego państwa wywołuje potrzebę odbudowy w Polsce polityki rozsądku (Piechociński, Konflikt PO)..

Jedną z nowszych potyczek w konflikcie PO-PiS jest sytuacja ze stycznia 2014 r. Podczas debaty poprzedzającej głosowanie Sejmu w sprawie odwołania Bartosza Arłukowicza z funkcji ministra zdrowia politycy PiS przywołali kwestię szpitala w Mysłowicach. Posłanka PiS zarzuciła radnym z PO, że kupili oni szpital wart 4,5 miliona złotych z kontraktem na 7 milionów za 135 tysięcy i nazwała ich „macherami z Platformy”. D. Tusk nie pozostał dłużny, zarzucając posłance oraz prezesowi PiS oszczerstwo, kłamstwo i insynuację. J. Kaczyński na wypowiedź D. Tuska zareagował nazwaniem PO ,partią oszustów i złodziei”. Marszałek Sejmu Ewa Kopacz po tych słowach oświadczyła, że skieruje tę sprawę do komisji etyki poselskiej (Tusk, dostęp 21.03.2014 r.). Wątpliwości nie ulega więc, że politycy obu partii znajdują wciąż nowe, mniej lub bardziej znaczące powody, by wymieniać się złośliwościami.

Analizując konflikt między PO a PiS, zauważyć można jednak pewne sztuczne jego aspekty i wysnuwać wniosek, że źródła konfliktu leżą 
w personalnych sporach między politykami obu partii i strategiach marketingowych, a nie w różnicach programowych. Obie partie popierają konserwatyzm obyczajowy oraz zajmują miejsce po prawej stronie sceny politycznej i odwołują się do konserwatywno-liberalnej tradycji politycznej. Choć dla PiS najważniejszą rolę odgrywa państwo, a dla PO samodzielność, to zauważyć można, że każda z tych kategorii jest także bliska przeciwnikowi. Dla PO państwo powinno pełnić rolę regulatora społecznego, musi być więc silne, a pożądany przez PO kształt rynku wolnego od ograniczeń jest zbieżny z tym pożądanym przez PiS. Obie partie deklarują przywiązanie do tych samych wartości konserwatywnych i religijnych. Można mówić o niemal identyczności metod realizacji celów PO i PiS. Łączy je także wiara w zbawienne skutki indywidualnej aktywności i zaradności. Między partiami nie występują więc liczne i znaczące przeciwieństwa. Jak widać, nie mają też one odmiennych koncepcji państwa i organizacji spraw publicznych. Generalnie powiedzieć można, że jest to jedno ugrupowanie, realizujące te same pomysły i reprezentujące interesy tych samych grup społecznych. Konflikt ten jest więc raczej wynikiem personalnych niechęci, niezaspokojonych ambicji i strategii marketingowych (Borezja, 2009, s. 10 - 12, 107 - 114).

Nie ulega wątpliwości, że konflikt między dwoma największymi partiami, nazywany konfliktem między Polską solidarną a liberalną, wpływa nie tylko na sytuację polityczną, ale wywołuje także kontrowersje w społeczeństwie. Zdania na ten temat są jednak podzielone. Według Doroty Litwin-Lewandowskiej dla Polaków spór ten ma istotne znaczenie i pozostaje ważnym elementem życia publicznego. Uważa ona, że ma on swoje odbicie także między wyborcami przeciwnych partii oraz jest nasycony agresywnymi i wrogimi postawami. Z kolei Adam Bobyk uważa, że Polacy nie przywiązują uwagi do potyczek między PO a PiS. Twierdzi, że jest to wojna głównie medialna, daleka od problemów rzeczywistych ludzi. Podkreśla też, że może być ona możliwością dla polityków chcących zaistnieć w mediach (Czy Polacy, dostęp: 08.03.2014).

W opinii autorki niniejszej analizy słuszna jest koncepcja D. Litwin-Lewandowskiej. Autorka uważa, że ten konflikt polityczny wpływa na życie społeczne i rzeczywiście zwolennicy obu partii bywają do siebie bardzo krytycznie nastawieni. Choć rzeczywiście środki masowego przekazu poświęcają mu wyjątkowo dużo uwagi, również w codziennym życiu Polaków dostrzegalna jest jego obecność. Istotny jest też fakt, że konsekwencji wpływu konfliktu PO-PiS na sferę codzien- 
nego funkcjonowania państwa i demokracji dopatrywać można się w braku możliwości wyboru między różnymi politycznymi opcjami. Choć pozornie wybór jest, nie ulega wątpliwości, że jest on sztuczny, ponieważ ostatecznie obie dominujące na polskiej scenie politycznej partie oferują to samo. Ludzie nie czują swojego wpływu na politykę, co przejawia się w dużej absencji podczas wyborów oraz przeświadczeniu o braku posiadania własnej reprezentacji w życiu publicznym (Borejza, 2009, s. 112 - 113). Według autorki spór między PO a PiS trafnie podsumował Rafał Matyja w artykule z września 2010 r. Wojnę między nimi nazwał on „sporem w rodzinie”, podkreślając, że istotą tego sporu jest sam spór. Według niego dzięki konfliktowi partie mogą ukryć swoje podobieństwa i dominować na polskiej scenie politycznej (Matyja, Wojna). Autorka uważa, że jest to trafne stwierdzenie i uważa, że politycy obu partii zdają sobie sprawę, iż to właśnie wciąż trwający konflikt gwarantuje nie tylko ich polityczną egzystencję, ale również jest warunkiem zachowania ich dominującej w stosunku do innych pozycji.

\section{ZAKOŃCZENIE}

JAK WIDAĆ, ISTNIENIE POLSKIEJ SCENY POLITYCZNEJ WOLNEJ OD KONFLIKTÓW nie jest możliwe. Wskazuje na to fakt, że dochodziło do nich już w pierwszych latach po wykształceniu się w Polsce nowego ładu, dochodzi i z pewnością dochodzić będzie. Nie ulega wątpliwości, że konflikty lat 1989-2005 różnią się jednak od tych współczesnych. Spory lat 1989-2005 to raczej sytuacje krótkotrwałe, wynikające głównie z różnicy poglądów między głową państwa a szefem bądź działaczami rządu. Zdecydowaną większość z nich udało się szybko rozwiązać, część z nich wygasła sama. Zupełnie inaczej podsumować można konflikty lat 2005-2014, które są bardzo długotrwałe. Nawet, gdy uda się je rozwiązać, pozostawiają one dużą niechęć i są powodem kolejnych sprzeczek. Różnicy można doszukiwać się także w sposobie prowadzenia konfliktów. Dzisiejsze konflikty są bardzo medialne. Często towarzyszy im wulgarny język oraz insynuacje. Politycy wiedzą, że obrażaniem przeciwników w wywiadach zyskują zainteresowanie, dlatego nawet, kiedy konflikt pozornie ucicht, jest przez nich podsycany na nowo. Współcześnie nawet dążenie do tych samych celów okazuje się niemożliwe ze względu na wzajemną niechęć. Nie ulega wątpliwości, że dziś, w dobie mediów nawet ludzie, którzy nie interesują się polityką, chcąc albo nie, mają z nią do czynienia. To, że konflikty polityczne wybuchały już w czasach kadencji pierwszego demokratycz- 
nego rządu oraz fakt, że konflikt między PO a PiS trwa od lat i wciąż wybucha na nowo pozwala wnioskować, że nie jest możliwa sytuacja pełnej zgody w polskiej polityce.

\section{Bibliografia:}

20. rocznica ,nocy teczek”. Premier Olszewski obalit się sam, http://wyborcza.pl/magazyn/1,126715,11854896,20__rocznica_nocy_teczek__Premier_Olszewski_obalil.html, 8.03.2014 r.

BorejzaT. (2009), POPiS. Pozorna opozycja, Warszawa.

Czy Polacy przejmuja się wojnq PiS i PO?, http://www.przeglad-tygodnik.pl/ $\mathrm{pl} /$ artykul/czy-polacy-przejmuja-sie-wojna-pis-po, 19.03.2014 r.

Daleko od Wawelu (2010), red. M. Majewski, P. Reszka, Warszawa.

Dudek A. (2007), Historia Polityczna Polski 1989-2005, Kraków.

Dziemidok-Olszewska B. (2007), Partie polityczne w wyborach 2005 roku $w$ Polsce, [w]: Partie i system partyjny RP Stan i perspektywy, red. K. Kowalczyk, Ł. Tomczak, Torun.

Figiel A. (2009), Języki IV RP: podziały spoteczno-polityczne $w$ dyskursie polityki, Poznań.

Golec A. (2002), Konflikt polityczny: myślenie i emocje. Raport z badania polskich polityków, Warszawa.

Jedynka POLSKIE RADIO, Wraca konflikt między PiS a PO, http://www. polskieradio.pl/7/129/Artykul/242333,Wraca-konflikt-miedzy-PiS-a-PO, 21.03.2014 r.

Leksykon politologii (2004), red. A. Antoszewski, R. Herbut, Wrocław.

Matyja R., Wojna PO i PiS, czyli spór $w$ rodzinie. Tak bliskie, tak dalekie, http://www.polityka.pl/tygodnikpolityka/kraj/1508404,1,wojna-po-i-pis-czyli-spor-w-rodzinie.read, 21.03.2014 r.

Money.pl, Konflikt PO z PiS. Wszystko przez katastrofę smoleńską, http:// prawo.money.pl/aktualnosci/wiadomosci/artykul/konflikt;po;z;pis;wszys tko;przez;katastrofe;smolenska,248,0,106956o.html, 21.03.2014 r.

Mucha J. (1987), Konflikt $i$ spoleczeństwo, Warszawa.

Opinie o koalicji AWS-UW, Komunikat z badań, CBOS, BS/87/200o, Warszawa 2000.

Piechociński: Konflikt PO-PiS jest zaprzeczeniem nauki Kościoła, do której obie partie nawiązują, http://www.polskatimes.pl/ artykul/552985, piechocinski-konflikt-popis-jest-zaprzeczeniem-naukikosciola-do-ktorej-obie-partie-nawiazuja,id,t.html, 21.03.2014 r.

Polskie konflikty A.D. 2013, Komunikat z badań, BS/141/2013, CBOS, Warszawa 2013. 
PSL-SLD czyli historia upadku czerwono-zielonej koalicji, http://www. rmf24.pl/fakty/polska/news-psl-sld-czyli-historia-upadku-czerwonozielonej-koalicji,nId,184650, 11.03.2014 r.

Reykowski J. (2002), Konflikty polityczne, [w]: Podstawy psychologii politycznej, red. K. Skarżyńska, Poznań.

Rząd Tadeusza Mazowieckiego - symbol przemian ustrojowych, http:// wiadomosci.wp.pl/kat,1342,title,Rzad-Tadeusza-Mazowieckiego-symb ol-przemian-ustrojowych, wid,16115791, wiadomosc.html?ticaid=11254c, 8.03.2013 r.

Sielski J. (2007), Czynniki zmian polskiego systemu partyjnego po 1989 roku, w: Partie i system partyjny RP Stan i perspektywy, red. K. Kowalczyk,

Ł. Tomczak, Torun.

Sobkowiak L. (1999),Konflikt polityczny - analiza pojęcia, [w]: Studia z teorii polityki, red. A. W. Jabłoński, L. Sobkowiak, Wrocław.

Sztumski J. (1987), Konflikt społeczny, Katowice.

Tusk zarzuca PiS kłamstwo. Kaczyński: PO to partia oszustów. Będzie wniosek do komisji etyki?, http://www.polskatimes.pl/artykul/3306910,tuskzarzuca-pis-klamstwo-kaczynski-po-to-partia-oszustow-bedzie-wniosekdo-komisji-etyki,id,t.html, 21.03.2014 r.

Wojciechowska A., Palikot J. (2011), Kulisy Platformy, Warszawa.

Ziętara W. (2007), Wybory parlamentarne i prezydenckie $w$ Polsce $w 2005$ roku, [w]: Partie i system partyjny RP Stan i perspektywy, red. K. Kowalczyk, Ł. Tomczak, Toruń.

Życiorys Tadeusza Mazowieckiego, http://www.premiermazowiecki.pl/zyciorys/, 8.03.2014

\section{SUMMARY}

The MAIN PURPOSE OF THE ARTICLE IS TO MAKE POLISH READERS CURIOUS ABOUT the issue of political conflicts during past 25 years and prove them that it is not possible to get rid of them in the political sphere. After explaining the phenomenon of political conflict and the definition, presenting the genesis and methods of solving, there have been presented political conflicts since 1989. First part of the article concentrates on the Polish way to a new democratic order and present political conflicts since the first democratic governments until year 2005 . The second part presents the most famous political conflict in years 2005-2014, namely the conflict between PO and PiS. The main purpose of the comparison of the conflicts over the years is to show the differences between them. 
Nota O AUTORCE

Mielcarek Joanna [asiam14@op.pl] - absolwentka studiów licencjackich na kierunku politologia na Wydziale Nauk Politycznych i Dziennikarstwa UAM, obecnie studentka zarządzania na Uniwersytecie Ekonomicznym. Interesuje ją polityka, historia Polski XX wieku i sfera społeczeństwa, szczególnie kwestie ludzkich zachowań. 